\title{
Free-Floating, Pigmented Cysts in the Anterior Chamber Causing Ocular Hypertension
}

\author{
Jessica S. Maslin Christopher C. Teng Miguel Materin \\ Ophthalmology and Visual Science, Yale University School of Medicine, New Haven, Conn., USA
}

\section{Key Words}

Ocular hypertension · Iris pigment epithelial cysts .

Free-floating cysts

\begin{abstract}
Purpose: The aim of this study was to describe the clinical and histopathological features of a 36-year-old male with hundreds of recurrent, unilateral, free-floating, pigmented cysts in the anterior chamber causing ocular hypertension. Procedures: The patient was referred to ocular oncology for blurry vision of the right eye and was found to have myriad pigmented, free-floating cysts in the anterior chamber and heavy pigmentation of the angle on gonioscopy. Anterior chamber washout was performed, and the fluid recovered was sent for pathological analysis. Results: The pathology report demonstrated rare nonpigmented epithelial cells, more consistent with iris stromal cysts or secondary implantation epithelial cysts. Conclusions: This paper highlights the first documented case of innumerable spontaneously occurring, unilateral, free-floating, pigmented cysts in the anterior chamber. While clinical diagnosis suggested iris pigment epithelial cysts, pathology suggested iris stromal cysts or secondary implantation epithelial cysts.
\end{abstract}

(c) 2016 S. Karger AG, Basel
(C) 2016 S. Karger AG, Base

$2296-4681 / 16 / 0024-0239 \$ 39.50 / 0$

\section{Case Report}

A 36-year-old Caucasian male presented to the Ophthalmic Oncology Program at Smilow Cancer Hospital at Yale for intermittent blurry vision in the right eye for the past 7 years. His past ocular history was significant for an anterior chamber (AC) washout in 2008 after presenting to an outside ophthalmologist with similar symptoms. There was no history of eye trauma or other eye surgery. He denied any pain, photophobia, or injection. His review of systems was only positive for occasional headaches without aura, flashes of light, or nausea or vomiting. His past medical history was negative for any medical conditions. His family history was significant for a brother with non-Hodgkin lymphoma. He denied any family history of ocular malignancy or glaucoma.

On ophthalmologic examination, the best-corrected visual acuity was $20 / 25$ in the right eye and 20/25 in the left eye. Pupils, extraocular movements, and external examination were unremarkable in both eyes. Slit-lamp examination demonstrated hundreds of mobile, free-floating, pigmented cysts in the AC of the right eye without cells or flare (fig. 1). With eye movement, the heavily pigmented cysts were found to be freely floating and mobile (online suppl. movie 1; for all online suppl. material, see www.karger.com/doi/10.1159/000446516). No pigment on the corneal endothelium was present. There were brown-colored pigment deposits on the anterior lens capsule of the right eye. Examination of the left eye was unremarkable. Intraocular pressure was $29 \mathrm{~mm} \mathrm{Hg}$ in the right eye and $15 \mathrm{~mm} \mathrm{Hg}$ in the left eye by applanation. Gonioscopy of the right eye revealed a flat iris approach with the angle open to scleral spur superiorly, with the other quadrants occluded by pigmented cysts with a heavily pigmented mesh-

\section{KARGER}

E-Mail karger@karger.com

www.karger.com/oop
Miguel Materin, MD

Ophthalmology and Visual Science, Yale University School of Medicine

Smilow Cancer Hospital at Yale New Haven Hospital

35 Park Street, Suite 8th Floor, New Haven, CT 06511 (USA)

E-Mail Miguel.Materin@yale.edu 


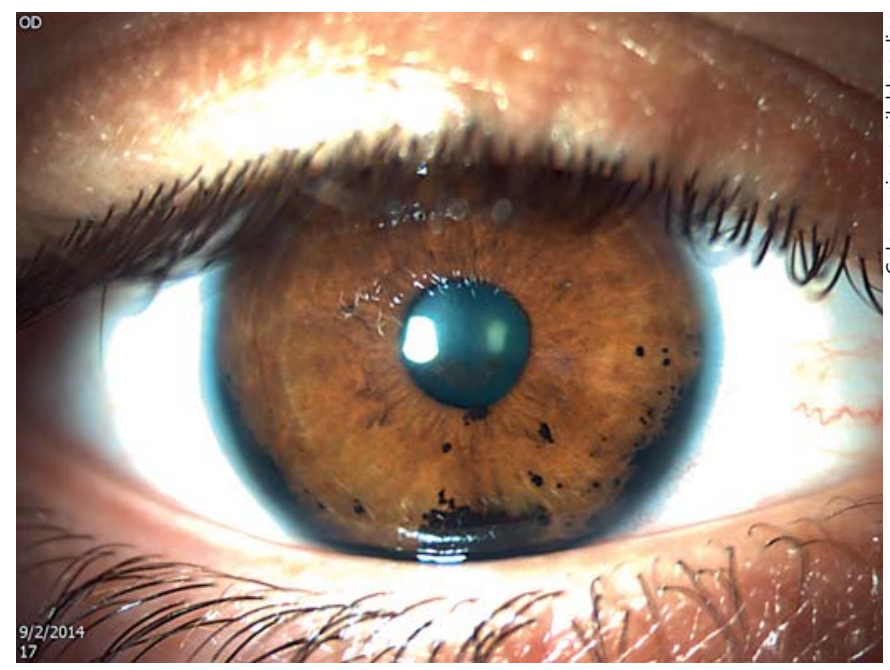

Fig. 1. Slit-lamp photograph of the right eye. Multiple pigmented lesions freely floating in the AC. See also online supplementary movie 1: with movement of the right eye, hundreds of pigmented cysts freely float in the AC.

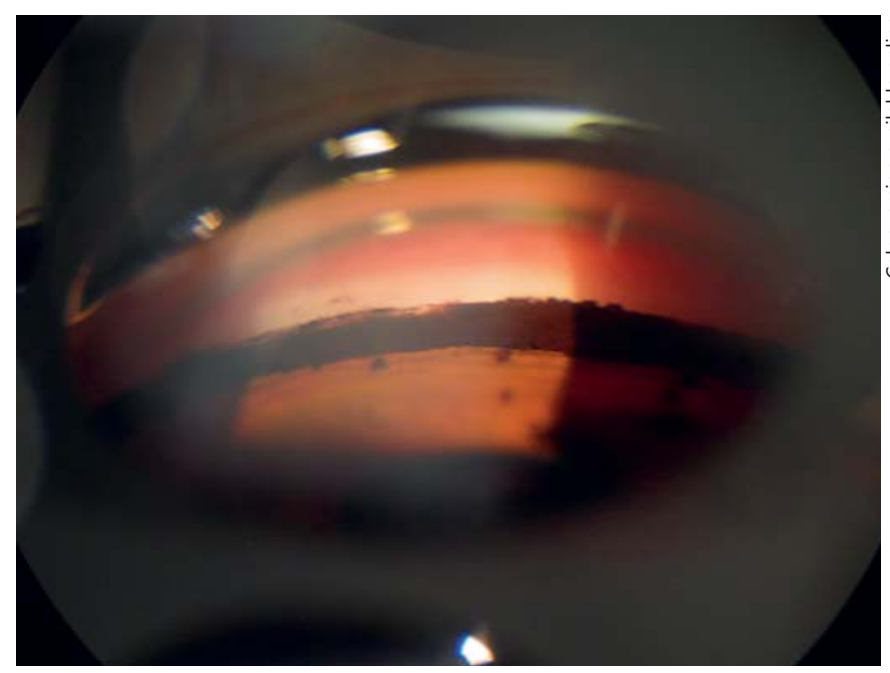

Fig. 2. Gonioscopy of the right eye: inferior angle demonstrating heavy pigmentation.

work (fig. 2). There was no neovascularization of the angle or peripheral anterior synechiae. Gonioscopy of the left eye was unremarkable. The funduscopic examination was unremarkable in both eyes, with a healthy optic nerve with a 0.3 cup-to-disc ratio in both eyes. An ultrasound biomicroscopy of the right eye was performed, which demonstrated no ciliary body or iris mass (fig. 3). Based on the examination, our differential diagnosis included iris pigment epithelial cysts as well as ring melanoma possibly shedding pigment and pigment-containing cells into the anterior segment chambers.

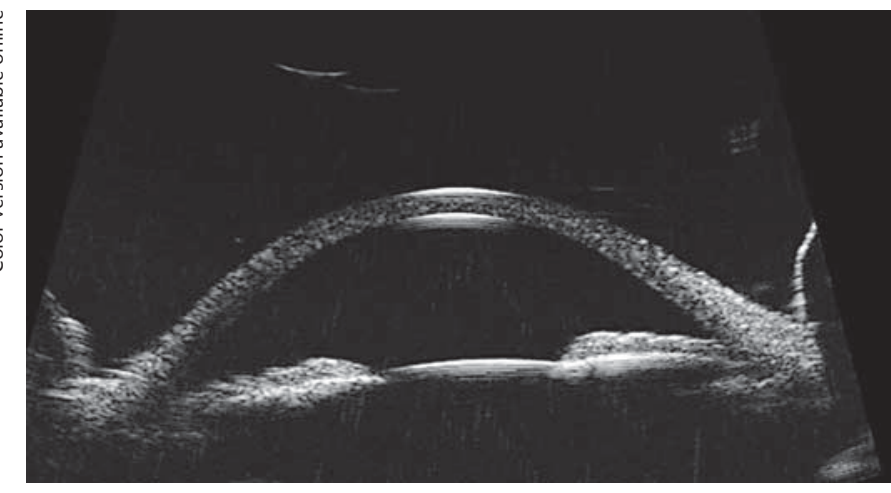

Fig. 3. Ultrasound biomicroscopy of the right eye was unremarkable.

Given the ocular hypertension, the patient was referred to the glaucoma service. His examination remained stable. His central corneal thickness was $586 \mu \mathrm{m}$ in the right eye and $584 \mu \mathrm{m}$ in the left eye. Reliable 24-2 visual fields were obtained and demonstrated scattered small central depressions which were greater in the right than in the left eye.

Outside records from 2008 were obtained from the previous ophthalmologist, who similarly described hundreds of free-floating pigmented cysts and performed an AC washout. This procedure resolved the symptoms of blurry vision and headache for 2 years before the floating pigment recurred. The pathology report from 2008 failed to provide a diagnosis due to nonsufficient material.

We made the decision to perform a repeat $\mathrm{AC}$ washout in the right eye. During the procedure, innumerable pigmented cysts were removed from the AC and sent for pathological analysis. The pathology report demonstrated rare nonpigmented epithelial cells, most consistent with iris stromal cysts or secondary implantation epithelial cysts. Following the procedure, there was improvement of the patient's symptoms and intraocular pressure.

\section{Discussion}

Free-floating iris cysts are extremely uncommon. This case is unique in the myriad small, floating, pigmented AC cysts, which may be either iris stromal cysts or secondary implantation epithelial cysts according to the pathology report. Iris stromal cysts are uncommon and clinically appear as a smooth, round, translucent mass in the AC, typically in children [1]. On pathology, iris stromal cysts appear as a nonkeratinized, squamous epitheliallined structure arising from within the iris stroma [2]. Free-floating iris stromal cysts have not been described in the literature before. Secondary implantation epithelial cysts result from implantation of epithelial cells on the iris after surgery or recent major trauma, and the mass typi- 
cally appears pearl-like or serous [3]. While there is a very small possibility of an introduction of epithelium during the AC washout in 2008, it remains unlikely that the patient's cysts were a result of secondary implantation, as the outside ophthalmologist's description of the lesions prior to 2008 was the same as in our examination prior to AC washout. Iris melanocytoma, which can liberate profound pigmentation during necrosis, was also considered in the differential diagnosis of this case; however, it was considered much less likely given no lesion on the iris and lack of ultrasound biomicroscopy findings suggesting this diagnosis.

There are several reports in the literature describing free-floating AC cysts but no known prior report describing a case with the number of cysts described in our case. Free-floating cysts have been typically described as iris pigment epithelial cysts rather than iris stromal cysts. In an observational case series of 234 patients with iris pigment epithelial cysts over a 20 -year period at Wills Eye Hospital, only 2 cases were of freely floating iris pigment epithelial cysts [1]. One free-floating (also called 'dislodged') cyst was in the AC, and 1 was in the vitreous.

There have been at least 10 prior case reports describing free-floating cysts in the $\mathrm{AC}$, the first published over
40 years ago [4-13]. Nearly all of these case reports describe 1 unilateral solitary free-floating cyst in a single patient. One report describes a 14-year-old boy with 2 free-floating cysts which caused visual disturbance and were successfully treated with YAG laser [10]. Three reports describe surgical removal of the cyst to treat visual disturbance and for diagnostic purposes [11-13]. A dislodged, free-floating AC cyst associated with neovascular glaucoma in a 7-year-old boy was removed and diagnosed as medulloepithelioma [11]. Two case reports describe a solitary free-floating AC cyst occurring in a young man, requiring surgical removal to treat visual symptoms $[12,13]$. The pathological diagnosis from both of these reports revealed that they were iris pigment epithelial cysts.

\section{Statement of Ethics}

The patient's consent was obtained for this report. This case report was exempted from our institution's committee on human research.

\section{Disclosure Statement}

The authors declare that there are no conflicts of interest.

\section{References}

1 Lois N, Shields CL, Shields JA, Mercado G, De Potter P: Primary iris stromal cysts. A report of 17 cases. Ophthalmology 1998;105:13171322.

2 Shields JA: Primary cysts of the iris. Trans Am Ophthalmol Soc 1981;79:771-809.

3 Marigo FA, Finger PT, McCormick SA, et al: Anterior segment implantation cysts. Ultrasound biomicroscopy with histopathologic correlation. Arch Ophthalmol 1998;116: 1569-1575.

4 Teong JM, Adler PA, Fuzzard DR: Free-floating iris cyst in a patient with recurrent iritis. Case Rep Ophthalmol 2015;6:176-179.

5 Collins ME, Hariprasad SM: Images in clinical medicine. Free-floating iris cyst. N Engl J Med 2010;362:1720.
6 Figus M, Ferretti C, Benelli U, Genovesi-Ebert F, Nardi M: Free-floating cyst in the anterior chamber: ultrasound biomicroscopic reports. Eur J Ophthalmol 2003;13:653-655.

7 Ghabrial R, Francis IC, McClellan KA: Freefloating pigmented iris cyst in the anterior chamber. Aust NZ J Ophthalmol 1991;19:7980.

8 Shields JA, Shields CL, DePotter P, Wagner RS, Caputo AR: Free-floating cyst in the anterior chamber of the eye. J Pediatr Ophthalmol Strabismus 1996;33:330-331.

9 Fine BS: Free-floating pigmented cyst in the anterior chamber. A clinic-histopathologic report. Am J Ophthalmol 1969;67:493-500.

10 Oner HF, Kaynak S, Koçak N, Cingil G: Management of free floating iris cysts in the anterior chamber: a case report. Eur J Ophthalmol 2003;13:212-214.
11 Zhou M, Xu G, Bojanowski CM, Song Y, Chen R, Sun X, Wang W, Chan CC: Differential diagnosis of anterior chamber cysts with ultrasound biomicroscopy: ciliary body medulloepithelioma. Acta Ophthalmol Scand 2006;84:137-139.

12 Verma L, Venkatesh P, Sen S, Lakshmaiah NC, Tewari HK: Surgical removal of a free floating cyst of the iris pigment epithelium causing disturbing visual symptoms. Ophthalmic Surg Lasers 1999;30:223-225.

13 Tang XY, Han W, Cui HG, Hu RR, Wang JY, Sun K: Surgical removal of a free-floating iris cyst in anterior chamber in a Han Chinese man. Acta Ophthalmol 2015;93:e514-e515. 